\title{
MUJERES Y ESPIRITUALIDAD: LAS BEATAS VALENCIANAS DEL SIGLO XVII. ${ }^{1}$
}

\author{
Francisco PONS FUSTER
}

INTRODUCCION.

M. Wade Labarge concluye su libro "La mujer en la Edad Media" afirmando que es necesario hacer un enérgico esfuerzo para recuperar del anonimato "las actividades y preocupaciones" de las mujeres, sobre todo, de aquellas que han dejado rastros menos evidentes, y que "los historiadores varones a menudo han pasado por alto inconscientemente o han considerado poco importantes porque rara vez tenían que ver con grandes movimientos o importantes acontecimientos políticos" $"$. Por eso, la misma autora advierte de los peligros que pueden suceder si nos centramos exclusivamente en los ejemplos más excepcionales, pues, éstos no son la guía más adecuada para conocer las actividades y capacidades de la mayoría de las mujeres ${ }^{3}$.

El peligro no parece excesivo cuando lo que pretendemos hacer es tratar los aspectos más singulares de la vida de un grupo amplio, y a su vez específico de mujeres, como es el caso de las beatas valencianas del siglo XVII.

"La Historia de las mujeres se inserta, sobre todo, en la Historia de la vida cotidiana"4. $Y$ si la vida religiosa es una fuente necesaria para estudiar la vida cotidiana de las mujeres en los siglos XVI y XVII, más lo es, si cabe, al ser nuestra pretensión la de adentrarnos en un mundo tan peculiar como era el de las mujeres beatas, bastante ignoradas por la historiografía y repudiadas por unas autoridades eclesiásticas para quienes,en general, la vida religiosa más adecuada para las mujeres era el enclaustramiento conventual, único lugar donde podían estar a salvo de las tentaciones y distracciones del mundo ${ }^{5}$.

1 Este artículo es un resumen del capítulo "El mundo enigmático de las beatas", incluido en mi Tésis Doctoral "La Espiritualidad Valenciana. El Iluminismo en los siglos XVI y XVII". La Tésis, dirigida por el Prof. Antonio Mestre, permanece inédita y fue leída en la Universidad de Valencia el 31 de Enero de 1989.

2 M. WADE LABARGE: La mujer en la Edad Media, Madrid, 1988, p. 298.

3 Ibid., p. 17.

4 MARILO VIGIL: La vida de las mujeres en los siglos XVI y XVII, Madrid, 1986, p. 2.

5 WADE LABARGE, La mujer en la Edad Media, p. 146. 
Bajo el apelativo de beatas se refugian diferentes acepciones: "Mujer que viste hábito religioso y vive con recogimiento, sin pertenecer a ninguna comunidad. La que vive con otras en clausura o sin ella bajo cierta regla. La mujer muy dada a toda clase de devociones", etc. ${ }^{6}$. Cualquiera de estas definiciones cuadra bien con la idea general que tenemos de as mujeres beatas.

Las beatas no son un fenómeno social exclusivo del siglo XVII. Desde los primeros tiempos del cristianismo hasta hoy en día, siempre han existido dentro de la Iglesia mujeres que han tenido un papel relevante por la forma singular de vivir su experiencia religiosa. Ejemplos así encontramos dentro de los movimientos de reforma espiritual de los siglos XIII y XIV, destacando por la afinidad que guardan con las beatas el caso de las beguinas?

También en el seno de las órdenes mendicantes, ante el empuje de hombres y mujeres que deseaban una vida religiosa fuera de los ámbitos conventuales, se arbitraron fórmulas como las Ordenes Terceras capaces de satisfacer las ansias de perfección espiritual.

El mundo de las mujeres beatas resulta hoy enigmático y poco conocido. La carencia de obras escritas de su mano hace difícil su estudio, y obliga a que nos tengamos que ceñir a las escasas biografías disponibles. En muchos casos, todo lo que de este mundo sabemos nos ha sido transmitido por confesores y maestros espirituales que, queriendo resaltar los grandes méritos de estas mujeres, escriben hagiografías exageradas.

Desde siempre, la mujer ha tenido un papel poco relevante en la espiritualidad. Su misma condición de mujer ha servido demasiadas veces como escusa simple para desprestigiar cualquier proyecto en el cual ella fuera la protagonista. En pleno siglo XVIII, y como simple ejemplo de los múltiples que podríamos traer a colación, Tomás Pérez, biógrafo de la beata de Guardamar Beatriz Ana Ruiz, dejaba su opinión, ciertamente curiosa, sobre las mujeres y su relación con los confesores. "Es muy cierto, que en la muger ay gran disposición para la piedad, como dixo Aristóteles: y para la benevolencia, economía, y otras virtudes, aun de las más heroicas, según Eurípides. Pero también es notoria la congénita aptitud de este sexo, para la nociva curiosidad, y nimio anhelo de saber, como lamenta toda la humana estirpe; arruinada por este vano apetito de nuestra primera Madre, en común sentir de los sagrados Intérpretes. Así no es mucho, que su Divina Magestad, vincule este desorden a la índole, y condición de la mujer. Es sin duda, pensión de la flaqueza; tan afín, y conexa con su ser: pues según san Gregorio, lo mismo es mujer, que mente flaca. Con todo ticnen entero alvedrío, para enfrenar su ingenio, y redimirse de la servidumbre, que rinden a su misma vanidad: que como dice el Señor, es andar sin libertad, esclavas de su ocasionada pasión de preguntar, y siempre dudosas, cansando Confesores, y consultando a los que venden sus ficciones, y sueños, por oráculos: y por esso muy expuestas a la ilusión"".

En un plano más específicamente espiritual, el dominico Alonso de la Fuente, incansable descubridor de Alumbrados por tierras de Extremadura y Andalucía, no dejaba de sor-

6 J. CASARES: Diccionario ideológico de la lengua española, Barcelona, 1959. Acepción "Beata".

7 Aspectos interesantes sobre la forma de vida de las heguinas pueden verse en: WADE LABARGE, $L a$ mujer en la Edad Media, pp. 131-157.

8 FRAY TOMAS PEREZ: Vida de la Venerable Madre Sor Beatriz Ana Ruiz, Valencia, en casa de Pascual García, 1744, p. 535. 
prenderse por el gran número de mujeres que encontraba dedicadas a la vida de oración y espiritualidad. El veía con malos ojos, "que una gente tan simple y de tan poco uso de las cosas de virtud tuviessen señales tan poderosas de santidad”. Para Fray Alonso, como para otros muchos eclesiásticos de la época, ciertas etapas de la vida espiritual estaban vedadas a la gente común; por eso, él se sentía ofendido, "porque había entre estas mujeres tanta ignorancia en las cosas generales de la ley de Dios, que apenas sabían las oraciones comunes de la Iglesia; y siendo los sujetos de esta especie, habían subido de golpe a la contemplación divina"s.

El dominico Fray Alonso tenía razón en una cosa: las beatas eran gente simple, del pueblo, con pocos estudios y muy humildes; sin embargo, es discutible su razonamiento de que estas mujeres no pudieran adentrarse en las etapas más altas de la escala espiritual. Para contradecir el juicio de Fray Alonso, están ahí los ejemplos numerosos de mujeres que con el beneplácito eclesiástico y, a veces, sin él, se dedicaron a vivir una vida espiritual de forma muy peculiar.

Las mujeres ocuparon un papel relevante en la espiritualidad valenciana del siglo XVII. Muchas de ellas permanecen en el más oscuro anonimato de las crónicas de las órdenes religiosas, en papeles manuscritos, o en obras impresas de dudoso interés hoy en día. Otras tuvieron más suerte, y sus nombres son conocidos, y comienza a estudiarse su influjo en el mundo espiritual. Muy conocidos son los ejemplos de Francisca Hernández y, sobre todo, de Isabel de la Cruz entre los Alumbrados de Toledo ${ }^{10}$. En el caso de Valencia, también se conocen los nombres de la beata Margarita Agulló, estrechamente vinculada al Patriarca Don Juan de Ribera y a otros personajes como Fray Pedro Nicolás Factor y San Luis Bertrán, y de Francisca Llopis, quien ejerció un gran influjo sobre el clérigo Francisco Jerónimo Simón, sobre Antonio Sobrino, sobre Miguel Molinos y otros.

En definitiva, las mujeres beatas no son un fenómeno irrelevante en la espiritualidad, ni tampoco todas ellas fueron ilusas, hechiceras, alumbradas, etc. El ejemplo de muchas de estas mujeres sirvió de acicate para otros. Su magisterio espiritual no quedó circunscrito al mundo laico, pues fue en el mundo religioso donde mejor se dejó sentir su impronta.

\section{LAS MUJERES BEATAS.}

Hombres y mujeres laicos tienen posibilidad de vivir su espiritualidad de manera más intensa a la común de cualquier persona. Pero, las mujeres son quienes destacan habitualmente por su vivencia especial de la religiosidad.

9 A. HUERGA: Historia de los Alumbrados. I. - Los Alumbrados de Extremadura (1570-1582), Madrid, 1978, p. 331.

10 Sobre los Alumbrados de Toledo existe una bibliografía abundante. Para el profano en el tema pueden serle de utilidad las obras de: ANTONIO MARQUEZ: Los Alumbrados. Origen y Filosofía 1525-1559, Madrid, 1972; DOMINGO DE SANTA TERESA: Juan de Valdés 1498?-1541. Su pensamiento religioso y las corrientes espirituales de su tiempo, Roma, 1957; M. MENENDEZ PELAYO: Historia de los heterodoxos españoles, Madrid, 1978. 
Averiguar las razones de por qué las mujeres son más conocidas como beatas nos llevaría a un estudio exhaustivo del papel que la sociedad del siglo XVII reservaba a la mujer" .

Sin entrar en profundidades que escapan a la finalidad de este trabajo, es posible aventurar algunas hipótesis razonables capaces de explicar el por qué muchas mujeres del siglo XVII buscaron refugio en una manera peculiar de vida religiosa como era el estado de beatas.

No es el siglo XVII un siglo fácil en España. A factores socio-económicos adversos hay que añadir la crisis política de la Monarquía. El hombre del siglo XVII tiene plena consciencia de estar viviendo unos momentos difíciles. En un marco general así siempre tienen mejor cabida las soluciones extremas. Las dificultades lanzarán a los caminos a los hambrientos, serán frecuentes las epidemias, el bandidaje se incrementará, etc. Pero hombres y mujeres no sufren por igual las consecuencias de los malos años. La sociedad está organizada en función del hombre, y a la mujer le reserva un papel secundario. 'Las crisis económicas y los cambios de coyuntura afectaban a las mujeres, en cuanto que afectaban a las familias enteras. Pero las mujeres no sólo dependían directamente de la coyuntura, sino también de la salud de sus respectivos padres o maridos. A una mujer podía irle relativamente bien económicamente y hundirse sólo por quedarse huérfana o viuda"12. Por eso, incluso las vías de escape propias de su sexo, convento y matrimonio, entrañan también ahora mayores dificultades.

Los conventos de mujeres están saturados en el siglo XVII. "En no pocos conventos se exigen pruebas de nobleza para ingresar". Las dotes necesarias sólo pueden ser ahora satisfechas por aquellas mujeres cuyas haciendas o progenitores alcanzan para aportar los recursos necesarios. Muchas veces, ni disponiendo de recursos es factible entrar en los conventos. En algunos casos, como ocurría en los monasterios femeninos de patronazgo real, había más ofertas de mujeres que pretendían entrar en ellos que plazas. Todo esto provocaba presiones por parte de la gente para que pudieran ingresar en los conventos hijas o familiares $^{13}$.

En cambio, los conventos de hombres continuaban manteniendo sus puertas abiertas a pesar de estar igualmente saturados. Nada o muy poco impedía a los hombres entrar en la vida conventual o clerical; su mera disposición personal era suficiente para conseguirlo.

El matrimonio es otra alternativa natural que la sociedad del siglo XVII ofrece a la mujer; pero, también ahora, éste tiene sus inconvenientes. Las guerras frecuentes de esta época suponen una sangría continua de hombres. A la desproporción numérica entre los sexos, hay que añadir ahora las guerras; sin olvidar, que "las depresiones económicas incidían negativamente en el número de matrimonios que se contraían, o los retrasaban. Lo cual afectaba directamente a las posibilidades de supervivencia material de las mujeres"14.

11 Sobre el papel de la mujer en la sociedad española del siglo XVII, vid: MARILO VIGIL, La vida de la mujeres en los siglos XVI y XVII.

12 Ibid., p. 114.

13 A. DOMINGUEZ ORTIZ: Las clases privilegiadas en la España del Antiguo Régimen, Madrid, 1973, pp. 321-324.

14 MARILO VIGIL, La Vida de las mujeres..., p. 114. 
Pero, quizás, causas menos catastrofistas expliquen mejor el porqué muchas mujeres optan por una vida religiosa tan peculiar como la de beata. La religión impregna todas las facetas de la vida en el siglo XVII. Clérigos y frailes desarrollan su magisterio entre el pueblo. Su trabajo no se limita al púlpito, oficiar Misa y otros menesteres específicamente eclesiásticos. Viven con el pueblo y sobre él ejercen su influencia. Dentro del pueblo, las mujeres son la parte del tejido social en más estrecho contacto con ellos. Para muchas, la asistencia a los actos litúrgicos es la única vía de escape del hogar. Ellas se muestran más receptivas a las doctrinas que se predican. Algunas quieren cambiar de vida y la religión les ofrece otras alternativas: vías donde dar salida a sus frustraciones, sublimar una vida matrimonial poco compensadora o, simplemente, desarrollar de manera más singular sus apetencias espirituales.

No sólo aspectos socio-culturales que podríamos denominar negativos condicionaron a las mujeres a la hora de escoger una forma de vida tan peculiar como era la de beata. Orellana, refiriéndose a los abundantes casos de emparedamientos de mujeres que existían en Valencia en el siglo XVI, tras resaltar el "prodigioso fruto y buen olor de santidad que difundieron dichos emparedamientos", refiere las razones que podían impulsar a las mujeres a adoptar esta forma de vida. Según él, "era esta una devota situación intermedia entre el riesgo peligroso del siglo, y la rígida clausura de la vida religiosa, para cuya suma austeridad de ésta, con el vínculo de los votos no siempre halla la fragilidad humana suficiente vocación, ni aún cuando la cree verdadera, está una persona libre del golpe de una inconstancia, bastando para el arrepentimiento lo invariable del estado, ni para la elección a veces ayudan o la edad o la posibilidad con el dote o el total desapego de Ios parientes. Descollando por otra parte la natural repugnancia a una entera subordinación con abnegación absoluta de la propia voluntad: aspirando no obstante un devoto espíritu a desviarse del tumulto y peligro bullicioso del siglo, vemos desaparecía la observancia y uso de dichos emparedamientos, que eran un virtuoso medio entre ambos a dos tan arriesgados extremos: y en algunas el de otra más tremenda resolución de perniciosísimas resultas (no pocas veces verificada) abalanzarse por despecho a un infeliz o forzado matrimonio" 15 .

\section{EMPAREDAMIENTOS DE MUJERES}

Ya hemos visto que para muchas mujeres entrañaba graves dificultades acceder a la vida conventual. A la inflación de mujeres en los conventos conviene añadir ahora la incompatibilidad entre convento y matrimonio. Pero existían otras soluciones. "No pocas mujeres, ante la dificultad de ingresar en un convento, formaban beaterios, llamados entonces emparedamientos, "congregaciones de doncellas y viudas que se recluían en una casa contigua a un templo, casi siempre una parroquia, a la que daban vista por medio de una reja o tribuna; obedecían al párroco, se mantenían de su trabajo o del producto de sus bienes, y con frecuencia guardaban la regla de S. Agustín"16.

La propia existencia de los emparedamientos denota, según R. de Maio, la lucha de la mujer por encontrar una vía media entre el monasterio y el matrimonio que le permitiera

15 A. ORELLANA: Tratado histórico apologético de las mujeres emparedadas, Valencia, 1887, p. 24.

16 DOMINGUEZ ORTIZ, Las clases privilegiadas..., pp. 321-322. 
desarrollar su propio individualismo. En este sentido, las mujeres emparedadas significarían la primera etapa de ese individualismo femenino, al que le seguiría "un movimiento de unión femenina que, aun dentro de su estatuto de vida común, defiende la soledad individual, la búsqueda de Dios a través de la contemplación, la oración como entrega social,el desarrollo de la feminidad en la maternidad espiritual". Al menos esto es lo que se puede concluir de los ejemplos de las capuchinas de Lorenza Longo, de las carmelitas de Teresa de Avila, de las visitadoras de Juana de Chantal y, también, de las beatas ${ }^{17}$.

En Valencia, a lo largo del siglo XVI, quizás como producto de la influencia ejercida en estas tierras por begardos y beguinas, o simplemente por las razones esbozadas con anterioridad, existían ejemplos de mujeres que, bien en sus casas solas o en comunidad con otras, emparedadas o no, dedicaban el resto de sus días a la religión. A estas conocemos con el nombre dee beatas; fenómeno social de indudable interés en la espiritualidad valenciana del siglo XVII.

M. A. Orellana, en su "Tratado apologético de las mujeres emparedadas" (Valencia 1887), pone de relieve la existencia de abundantes casos de emparedamientos en Valencia durante el siglo XVI. Junto a emparedamientos forzados de mujeres motivados por la imposición de penas o castigos por conductas contrarias a la Ley; Orellana refiere casos de emparedamientos que obedecen a motivaciones puramente religiosas. En este caso, los emparedamientos eran voluntarios, elegidos libremente por las mujeres. "Como esta era una nueva constitución de vida, aunque arbitraria, era a elección de las que la abrazaban, las de mayor edad solteras o viudas como dueñas en disponer de su persona, hallándose con vocación de tal retiro, elegían el que querían según y cómo les era bien visto. Pero las de menor edad, sugetas a la debida y discreta subordinación de sus Padres o parientes, que las autorizasen, solían hacerlo con previo dictamen y aprobación de los mismos, y de su Director espiritual..."18.

La expresión emparedarse no debe ser entendida literalmente como encerrarse entre cuatro paredes sin comunicación alguna con el mundo exterior. Para Juan Bautista Corachán, damos el nombre de emparedamiento,"por ser un encerramiento o sitio retirado en que se constituían para morar de propósito con el fin de tener oración, vivir a Dios soló, y no dejarse ver del público más que en lo muy preciso, abstrayéndose del trato y comercio del siglo, y vivir entre cuatro paredes"19. A pesar de estas precisiones, creemos que no existe diferencia alguna entre emparedamiento, beaterio y eremitorio. Cualquiera de estas acepciones es válida para expresar la idea de que una mujer o varias vivieran retiradas del mundo dedicándose a la oración. Quizás por eso, para Orellana, mujeres "como la Soriana, la Zucala, que observaron en su casa una vida retirada y devota, al paso que efectuaron con fervoroso celo célebres y devotas fundaciones: tampoco otras virtuosas mujeres como la María Luisa Zaragozá, la Josepha Benlloch y Albors, la Leocadia Estopina, la Gerónima Dolz, la Madre Francisca López, la Agullona, la Magdalena Llorca, la Ursula Aguiz, Ana Albuixech, Juana Ana Serret y otras infinitas valencianas, que guardando una voluntaria clausura en su casa, y algunas de éstas en su reducida mansión en algún Beaterio, pueden

17 R. DE MAIO: Mujer y Renacimiento, Madrid, 1988, p. 24.

18 ORELLANA, Tratado..., p. 15.

19 Cit. en ORELLANA, Tratado..., p. 21. 
también llamarse Emparedadas por verificarse en ellas el vivir entre cuatro paredes y en voluntario retiro, con aquella segregación y abandono del siglo que las concilia dicho renombre..."

A lo largo del siglo XVI existen abundantes casos de mujeres emparedadas en Valencia. Adosadas a algunas parroquias habían casas donde vivían mujeres encerradas dedicadas a la oración. En la Parroquia de S. Andrés vivía emparedada en 1531 una beata llamada Quiteria de Mora y, en 1578, la beata sor Ana Sanchiz. También en la Parroquia de S. Lorenzo, sujetas a la regla de la Orden Franciscana, vivían emparedadas en 1571 las beatas Magdalena Calabuig, Catalina Vesant, Gerónima Franca y Esperanza Aparicio. Todavía en 1595, residían en esta parroquia tres de las beatas antes citadas. Casos parecidos de emparedamientos tenían lugar en las parroquias de S. Esteban, Santísima Cruz, Santa Catalina, y en otras de la ciudad y reino de Valencia.

Un caso singular de emparedamiento lo constituye el de Angela Genzana de Palomino. Esta beata se vio obligada a salir de su retiro en 1611, cuando llevaba treinta años emparedada, porque la Iglesia de $\mathrm{S}$. Esteban amenazaba con derrumbarse.

Especial importancia dentro de la ciudad de Valencia tiene en el siglo XVI el beaterio de la calle Renglóns. Este beaterio se constituyó en 1528, cuando las beatas del convento de Jerusalén se trasladaron a una casa ubicada en dicha calle. Allí vivían en comunidad un grupo de mujeres sujetas a la regla de $\mathrm{S}$. Francisco. El beaterio era prolongación de otro que se había fundado en Valencia en el siglo XIII. Muchas mujeres brillaron con su ejemplo en este beaterio, destacando en el siglo XVI la importante figura de Margarita Agulló ${ }^{21}$.

Fuera de la ciudad de Valencia, fueron muy conocidos los emparedamientos de Bocairente, Onda, El Puig y Liria.

Según narra Viciana, en Bocairente existía un monte donde había "un emparedamiento de siete honestas, y venerables mujeres emparedadas. La primera que se emparedó fue sor Cecilia Ferré: la cual vino del emparedamiento de Santa Cruz de Valencia. Esta casa fue comenzada en el año 1537, y en el año 1544 se encerró la primera emparedada en esta Iglesia so título de Monte Calvario. Estas emparedadas llevan hábito de la tercera regla de S. Francisco"22.

En el caso de Onda, la crónica de Viciana se muestra más explícita: "Y en la iglesia (de Onda) hay un emparedamiento donde están encerradas seis honestísimas mugeres Beatas, con el hábito y regla de S. Francisco, y son habidas por un dechado de virtud y santidad de vida. Y siempre suele haber en este emparedamiento algunas mugeres muy exemplares y provechosas para las honradas familias de Onda, y para rogar al Señor por el bien y conservación de la tierra" 23 .

El emparedamiento de Onda fue fundado por Leonor Forés. Esta mujer, al quedar viuda, vivió en Valencia con su hija Angélica durante once años. Disponiendo de hacienda,

20 Ibid., pp. 18-19.

21 Noticias sobre este beaterio en: E. ALCOVER: Historia de la Congregación de Religiosas Terciarias Franciscanas de la Inmaculada. Orígenes, Valencia, 1974, pp. 19-61.

22 Cit. en ORELLANA, Tratado..., p. 12.

23 Ibid., pp. 12-13. 
"dedicóse al recogimiento, siendo su empleo visitar Iglesias y frecuentar Sacramentos, y para mayor perfección tomó el hábito de la tercera orden de penitencia de S. Francisco, en el cual vivió once años en Valencia, con recogimiento y grandes muestras de santidad". Esta forma de vida no debía colmar sus aspiraciones y, finalmente, decidió trasladarse a Onda para encerrarse con su hija y otra mujer llamada Leonor Masquefa ${ }^{24}$.

Por lo que se refiere al emparedamiento o beaterio existente en Liria, éste tenía algunas peculiaridades respecto a los otros: las mujeres "no viven tan libres, guardan reglas y constituciones de comunidad, con Prelada que llaman Mayorala, visten cierto trage como hábito, entran precediendo pruebas de su morigerada vida, hay número determinado de solas 15 contando la Mayorala, no admiten sino doncellas; guardan total encierro de noche, y aunque no hacen voto alguno, empero no hay ejemplar que jamás haya salido Beata alguna para casarse, reciben alguna mediana asistencia de dicha villa, la que igualmente las asiste en lo espiritual" 25 .

Un caso singular de emparedamiento en cueva lo constituye el de Inés Pedrós de Alpicat. Esta mujer, más conocida como la Venerable Inés de Moncada, huyó de la casa de sus padres siendo niña, y se refugió en una "encumbrada e inaccesible cueva en los montes de Porta-Coeli". Aquí vivió durante toda su vida disimulando su sexo con trages de hombre, hasta que a su muerte se descubrió que era una mujer ${ }^{26}$.

Dominga Torres es un ejemplo de ermitaña a la que podemos calificar también como beata o emparedada. Esta mujer, sometida, según sus biógrafos, a continuas violencias satánicas, vivió muchos años como ermitaña en una ermita de Masamagrell. De aquí se trasladó al beaterio que el reformador dominico Juan Micó había fundado en Valencia por los años de 1550-1555. Este beaterio fue muy importante, pues, en el mismo llegaron a congregarse más de cincuenta beatas de la tercera orden de Santo Domingo ${ }^{27}$.

\section{PROCEDENCIA SOCIAL DE LAS BEATAS.}

No todas las beatas tienen el mismo origen social. La cuna es un factor importante que separa a unas de otras. En algunos casos, la cuna marca la adopción de una determinada forma de espiritualidad; en otros, será la elección de la familia religiosa lo que determine esto.

Los autores de biografías de beatas no pretenden esconder la bajeza social de sus retratadas, pero utilizan formas estereotipadas y barrocas para referirse a ello: "de honestos padres, no ricos, según la estimación del siglo, pero la verdad muy dichosos, pues merecieron tener tal hija"28; "pobres, pero honestos y trabajadores"29. En otros casos, cuando el origen

24 Ibid., p. 13.

25 Ibid., p. 31.

26 Ibid,, p. 19. Sobre la beata Inés Pedrós i Alpicat, vid: A. ROBLES: "Manuscritos del Archivo del Real Convento de Predicadores de Valencia", en Escritos del Vedat, vol. XIV (1986), pp. 349-402. Robles informa de que en dicho Archivo se conserva un manuscrito cuyo autor es Fray Vicente Gómez y que lleva por título: Vida y muerte de la venerable Inés Pedrosa, Valencia, 1636.

27 Ibid., p. 19. Sobre Dominga Torres vid: Biblioteca de la Universidad de Valencia, Ms. 159, fols. $272 \mathrm{v}-278 \mathrm{v}$.

28 ANTONIO PANES: Chrónica de la Provincia de S. Juan Bautista de religiosos menores de la regular observancia de nuestro padre seráphico S. Francisco, Valencia, 1665-1666, vol. II, p. 694.

29 PEREZ, Vida de la Venerable..., p. 7. 
social es relevante, los biógrafos no dudan en señalarlo: "era de lo más calificado y rico de aquella villa"30.

Si las circunstancias socio-económicas dejan poco margen para el ascenso social, la vida espiritual dentro del mundo no parece el modo más adecuado para conseguir cambiar de clase. Las beatas, pues, no son una excepción en esto. Mujeres de su tiempo, viven dentro de su medio social, teniendo que trabajar para ganarse el sustento y teniendo que sufrir como la sociedad en la que viven los rigores y las bonanzas de los tiempos.

La beata Inés Juana García estaba tan obligada por su madre,"que de coger seda",se le lisiaron las manos. Le ocupaba tanto tiempo su trabajo que no podía dedicarse a la oración. Si algún tiempo descuidaba su trabajo y oraba, pillándola su madre, "la castigava muy ásperamente, dándole con un palo"31. Las hermanas Isabel y Ana de Medina, pese a que su casa "era de las bien puestas, y acomodadas que avía en Villena", ayudaban a sus padres tejiendo en un telar de su casa ${ }^{32}$. Beatriz Ana Ruiz, beata de Guardamar, tuvo que dedicarse a lavar ropa ajena primero y, después, a pedir limosna para poder sustentarse ${ }^{33}$. Un ejemplo excepcional, aunque no parece que en este caso ella buscara su sustento con el trabajo, lo tenemos en la beata María de Jesús. De ella refiere su biógrafo Antonio Panes: 'Su ordinaria comida eran hojas de verças o las cortezas de melón que se hallava por los muladares: éstas cozía con agua, y les echava un poco de pimienta y ajo con muy poco azeyte, y comía dello, y si caso le sabía bien, mezclava cantidad de ceniza, para que perdiese el sabor". No probaba nunca la carne, y el pan que comía estaba tan mohoso y duro," que era necesario partirlo con una piedra"34.

Pero hubo mujeres que después de un cierto tiempo de ser beatas no necesitaron trabajar para alimentarse. Conseguida una cierta fama de santidad e incluso hijos espirituales, vivían de la caridad y regalos de personas notables que las atendían y daban dinero para que se sustentaran.

Francisca Llopis tuvo muchos valedores a lo largo de su prolongada vida. Trabajó durante un tiempo en su casa, sin que su madre acabara de comprender su manera de vivir: "ni pares, ni crías, ni sirves marido, como tus hermanas"35. Pero la excelencia de su vida espiritual hizo que su confesor, el jesuita Miguel Fuentes, dado que "el sujeto era tan delicado, y flaco para trabajar, y el exercicio de la oración continua la tenía, quanto a lo exterior, casi consumida, y desecha; y sino trabajava, no tenía con que sustentarse", a buscarle un hacedor. Entonces, su confesor "rogó a un hijo suyo muy espiritual y devoto, Ciudadano de Valencia, llamado Ponze, que cada semana le acudiesse con una limosna que vendría a ser como quarenta o cinquenta escudos al año; y con esto vivía la sierva de Dios, y su madre, que ya era viejíssima, sin tener ni solicitud, ni codicia de más averes de la tierra, ni otro humano arrimo, ni propiedad en ella"36.

30 PANES, Chrónica ..., II, p. 464.

31 Ibid., pp. 450-451.

32 Ibid., I, p. 384.

33 PEREZ, Vida de la Venerable..., pp. 18-21.

34 PANES, Chrónica..., II, pp. 414-415.

35 Ibid., p. 725.

36 Ibid., pp. 717-718. 
En la vida de Inés Juana García tuvo que intervenir San Luis Bertrán para que su madre le permitiera dedicarse a la religión. Con el fin de que no se perdiera un espíritu tan noble, San Luis le daba a la madre tres sueldos, y continuó dándoselos mientras vivió. Pero además de San Luis, la beata tuvo también la protección de la Duquesa de Frías. "Mientras estuvo la duquesa en Valencia, demás de darle todo lo necessario para ella, y una criada, le hazía otras particulares limosnas; y aviéndose ido, no se olvidava de socorrerla. Embióle desde Milán en una ocasión cien ducados, y otras vezes dentro de las cartas la remitía algunos doblones, rogándole no se olvidasse della, y de toda su casa"37.

También Elena Martínez encontró su protector. Hija espiritual de Fray Antonio Sobrino, éste consiguió que D. Francisco Calderón, padre de D. Rodrigo Calderón, privado de Felipe III, le enviara todos los años una ayuda económica para la beata ${ }^{38}$.

Finalmente, especial relevancia merece el ejemplo de la beata Beatriz Ana Ruiz, quien después de una vida salpicada de escándalos, encuentra protección en el Secretario del Ayuntamiento de Guardamar, Miguel Pujalte. Este, todavía casado y con hijos, no duda en ayudar a la beata con todos los medios a su alcance. Más adelante, cuando Pujalte se hace sacerdote, continúa su protección hacia Beatriz, hasta el punto de llevársela a ella y a sus tres hijos a vivir con él ${ }^{39}$.

La baja extracción social de la mayoría de las beatas va acompañada de un nivel cultural acorde a su condición social, pero no exclusivo de ella. "En la realidad, el nivel cultural de las mujeres durante el siglo XVI, y sin duda también en el siglo XVII, fue muy bajo, a pesar de que hubo una situación favorable para la educación femenina por la influencia de los humanistas. Pero las mujeres no se mostraron muy interesadas por este asunto. En los testimonios de los moralistas y de la literatura apreciamos la existencia de una fuerte pugna femenina para romper la clausura doméstica, pero no detectamos una lucha paralela de las españolas por elevar su nivel cultural...el avance que se produjo en cuanto a la libertad de movimientos no fue paralelo a un progreso en el nivel educativo" 40 .

El bajo nivel cultural del conjunto de las mujeres no es una excepción en el caso de las beatas. Estas, en su mayoría, no sabían leer ni escribir y, a pesar de ello, fueron capaces de adentrarse por caminos espirituales difíciles. Lo que no resulta contradictorio si tenemos claro que la vía espiritual no necesita tanto de conocimientos intelectuales, como de un método de aprendizaje reiterativo. Por otra parte, el nivel cultural que podía significar la posiblidad de lectura de los tratadistas místicos, si era de desear respecto a lo que pudiera significar de mejora en el nivel cultural de las mujeres, también entrañaba sus peligros desde el punto de vista doctrinal. "Los efectos internos de la lección de las obras de los grandes místicos, en su época y algo después, fueron grandes. No todos positivos, ni mucho menos. Porque en una sociedad sobrecargada de clérigos, frailes y monjas, de hombres y mujeres píos, hubo de darse por fuerza, repetidas veces, el caso del hombre o la mujer sugestionado por los textos que corrían y servían de pasto espiritual, que se lanzó a lo que podría llamarse aventura mística y que fue derrotado tristemente en ella"4!

37 Ibid., pp. 456-459.

38 Ibid., pp. 498-501.

39 PEREZ, Vida de la Venerable..., pp. 98-100.

40 MARILO VIGIL, La Vida de las mujeres..., p. 52.

41 J. CARO BAROJA: Las formas complejas de la vida religiosa. Religión, sociedad y carácter en la España de los siglos XVI y XVII, Madrid, 1985, p. 53. 
Teresa de Jesús se quejaba con amargura de haber andado más de veinte años desorientada en la vida espiritual por no haber encontrado buenos maestros de espíritu. "Porque yo no hallé maestro, digo confesor que me entendiesse, aunque lo busqué, en veinte años después de esto que digo". Confesores y maestros ineptos, -iletrados los llama ella-, confundían su espíritu; "lo que era pecado venial, decíanme que no era ninguno; lo que era gravísimo mortal, que era venial" 42 .

La guía espiritual resulta imprescindible para quienes pretenden adentrarse en la contemplación mística; pero la elección del confesor o maestro no siempre es tarea fácil. Miguel Molinos planteaba la elección de la guía como algo trascendente: "Antes que se elija el Padre espiritual, se ha de pensar bien y se ha de hacer oración, porque es materia gravísima y ha de venir de la mano de Dios" ${ }^{\prime 3}$.

En cuanto a la disyuntiva entre maestros espirituales o libros de espiritualidad, los grandes teóricos del siglo XVII se decantan siempre por la primera opción. "Hay una gran ventaja en tener maestro en el camino místico, a servirse de los espirituales libros; porque el maestro práctico dice a su tiempo lo que se debe hacer, y en el libro leerá aquello que menos convendrá, y de esa manera falta el documento necesario"44.

Una vez elegido confesor o maestro, hay que mantenerse fiel al mismo. Nada de querer averiguar si otro nos irá mejor o de consultar con otros la elección: "no te andes más de consulta en consulta, queriendo saber de este confesor, y del otro, o Maestro, si va bien en este modo de oración, porque te dirá cada uno un consejo diferente, y aún te perturbarán harto, sino entienden mucho de ello, y te dirán, que vas perdido y que es tentación, con que te harán gran daño..." ${ }^{\prime 4}$. Solamente una serie de causas deben inducir a cambiar de maestro. "El no ser, pues, experimentada la guía, es la principal causa para dejarle y elegir otra, que lo sea, porque sin ella no se aprovechará el alma"46.

La fidelidad de las beatas a sus confesores o maestros es una dato contastable. Inés Juana García mantuvo como confesor durante doce años al "varón extático, e iluminado de la sabiduría divina" Pedro Nicolás Factor. Teniendo en cuenta los años que vivió la beata, "más de noventa años", ésta tuvo otros confesores ${ }^{47}$.

Francisca Llopis tenía más de ochenta años cuando murió. Muchos confesores gobernaron espiritualmente su vida; pero la fidelidad de la beata por ellos no fue cosa de pocos años. Siete años tuvo como confesor al P. Gerónimo Mur de la Compañía de Jesús; después, confesó catorce años con otro jesuita, el P. Miguel Fuentes. "Tratóla también muchos años el P. Miguel Julián...". Finalmente, tuvo como maestro a Fray Antonio Sobrino, quien

42 Cit. en: CRISOGONO DE JESUS SACRAMENTADO: Santa Teresa de Jesús. Su vida y su doctrina, Barcelona, 1942, pp. 35-36.

43 M. MOLINOS: Guía Espiritual, ed. a cargo de J. I. Tellechea Idígoras, Madrid, 1975, p. 202.

44 Ibid., p. 205.

45 FRAY JUAN FALCONI: Camino derecho para el cielo, ed. a cargo de Elías Gómez, Barcelona, 1960, p. 293.

46 MOLINOS, Guia..., p. 202.

47 PANES, Chrónica..., II, pp. 451-452. 
gobernó espiritualmente su alma hasta su muerte en 1622. Fallecido Sobrino, Francisca continuó el trato con otros espirituales, pero ya entonces, su fama de santidad era tan grande en Valencia, que pasó a ser más maestra que hija espiritual ${ }^{48}$.

Tema conflictivo y no exento de peligros, sobre todo teniendo en cuenta los casos frecuentes de solicitaciones, abusos, posesiones diabólicas, etc. que se daban en la época, era el de la preparación que debían tener aquellos que se dedicaban a la guía de almas ${ }^{49}$. Para Miguel Molinos, tres requisitos debían reunir quienes quisieran dedicarse a este trabajo: luz, experiencia y vocación. "Te parecerá, y con satisfacción, que eres a propósito para guiar almas por el camino del espíritu, y quizás será soberbia secreta, ambición espiritual y conocida ceguedad, porque a más de pedir este alto ejercicio superior luz, total desapego y las demás calidades..., es necesaria la gracia de la vocación, sin la qual todo es vanidad, satisfacción y propia estima"50.

\section{PENITENCIAS Y MORTIFICACIONES DE LAS BEATAS.}

Penitencias y mortificaciones corporales están presentes en la vida de las beatas. Este aspecto es interesante porque la mayoría de las biografías que utilizamos fueron escritas por el franciscano descalzo Antonio Panes, a quien algunos identifican con el quietismo ${ }^{51}$. Es importante resaltar esto, pues, una de las características que se utilizan para diferenciar a alumbrados y quietistas de los espirituales que llamaremos ortodoxos, es el poco apego de los primeros por las mortificaciones y penitencias en el camino de la contemplación mística.

Miguel Molinos, autor espiritual condenado en 1687 por sus doctrinas quietistas, analiza en uno de los capítulos de su "Guía Espiritual" el tema de las penitencias y mortificaciones corporales. "El sustento del alma, dice Molinos, es la oración, y el alma de la oración es la interior mortificación: porque aunque las penitencias corporales y todos los demás ejercicios con los cuales se castiga la carne, sean buenos, santos y loables (mientras sean con discreción moderados, según el estado y calidad de cada uno, y por el parecer del espiritual director), sin embargo, no granjearás virtud alguna por estos medios, sino vanidad y viento de vanagloria, si no nacen del interior ${ }^{52}$.

Para Miguel Molinos queda claro que la mortificación corporal sin más no tiene sentido alguno. Debe ser el director espiritual, como persona experimentada, quien diga cuándo y qué penitencias deben hacerse. Si se carece de director espiritual, sólo interiormente se

48 Ibid., pp. 687-689.

49 Sobre el nivel cultural del mundo eclesiástico, vid: A. DOMINGUEZ ORTIZ: “Aspectos sociales de la vida eclesiástica en los siglos XVII y XVIII", en Historia de la Iglesia en España, vol. IV, Madrid, 1979, pp. 5.72 .

50 MOLINOS, Guia..., pp. 217-218.

51 Esta es, al menos la opinión de R. Robres. Vid: R. ROBRES: "En torno a Miguel Molinos y los orígenes de su doctrina. Aspectos de la piedad barroca en Valencia", Anthologica Annua, 18 (1971), pp. 353 465. Una respuesta matizada a las opiniones de Robres, puede verse en el capítulo de mi tésis titulado "La espiritualidad valenciana y Miguel Molinos", pp. 686-728.

52 MOLINOS, Guia..., pp. 260-261. 
puede saber si se necesita o no mortificar el cuerpo; de lo contrario se incurre en vanidad, cuando no en cuestiones más graves como los de fingimientos de "Ilagas, azotes, coronas de espinas y Cristos en los pechos..." 53 .

Las penitencias corporales no siempre son válidas en el camino espiritual. "Cuando el alma comienza a retirarse del mundo y del ocio, debe domar el cuerpo con rigor para que se sujete al espíritu y siga la ley de Dios con facilidad. Importa entonces jugar las armas del cilicio, ayuno y disciplina, para arrojar de las carnes las raíces del pecado. Pero cuando el alma se va entrando en el camino del espíritu, abrazando la interior mortificación, se deben templar las penitencias del cuerpo, por estar bastántemente trabajado del espíritu: el corazón se debilita, el pecho padece, el celebro se cansa y todo el cuerpo queda pesado e inhábil para las funciones del alma" ${ }^{\prime 54}$.

Toda una gama de penitencias y mortificaciones figuran en las biografías de las beatas. Francisca Llopis, que "no pudo lograr las ansias, que siempre tuvo de hazer penitencia tan rigurosa como demandava su fervoroso espíritu", dormía vestida sobre unas tablas, "no se desnudava, y que siempre dormía abraçada a un Crucifixo" 55 .

El crucifijo es un utensilio penitencial de uso común por las beatas. Margarita Agulló hacía oración abrazada a una cruz de madera que se había hecho a propósito, al menos esto es lo que narra haber presenciado personalmente el Patriarca Juan de Ribera ${ }^{56}$. La beata María de la Concepción, conocida con el nombre de Ginesa de la Rosa, además de cilicios, disciplinas, ayunos y otros penitenciales utensilios, "tenía una Cruz grande, mayor que la estatura del cuerpo arrimada a la pared, un poco sacado el pie afuera, con tres clavos grandes; de los quales todas las noches estava pendiente tres horas, y muchas vezes perseverava las noches enteras; puestos los pies en el clavo inferior, y colgado el cuerpo de los otros dos, enlaçando las manos en unos cordeles". Era tanto el dolor y la "dulzura" que al mismo tiempo experimentaba, que apostilla su biógrafo: "No pueden dezir los testigos más que la penalidad exterior, pero la dulçura que, su alma sentía, siendo transformada por el compasivo afecto, y piedad en los dolores de nuestro Redemptor, queda el ponderarlo a juizio del varón espiritual, pues tanto aliento en el padecer, no es dado a la flaqueza humana sin grande embriaguez. y olvido del penoso sentir, en el contemplativo gozar"57.

Los sufrimientos padecidos por Cristo también son utilizados penitencialmente por las beatas. Así, Ana García Rubia "se ponía en la cabeza una corona que avía hecho de agudas espinas" 58 .

El carácter imitativo que en algunos casos tienen las mortificaciones de las beatas, lleva a éstas hasta el extremo de cuantificar los sufrimientos padecidos por Cristo, para así poder domar su cuerpo con los mismos. Cinco mil azotes creía Ana García Rubia que había reci-

53 Cit. en CARO BAROJA, Las formas complejas..., p. 60

54 MOLINOS, Guía..., p. 261.

55 PANES, Chrónica..., II, pp. 720-721.

56 J. BUSQUETS MATOSES: Idea exemplar de prelados delineada en la vida y virtudes del venerable varón el Illmo. y Exmo. Señor D. Juan de Ribera, Valencia, 1683, pp. 356-365.

57 PANES, Chrónica..., II, p. 160.

58 Ibid., p. 432. 
bido Cristo cuando estuvo atado al poste del martirio, y cinco mil azotes procuraba darse la beata en sesiones espaciadas de días. Solamente la intervención de su hijo, fraile franciscano, disuadió a la beata de práctica penitencial tan peregrina $a^{59}$.

Cilicios de todos los tamaños, modelos y formas son utilizados por las beatas. Ana García Rubia, no satisfecha con llevar un traje áspero y grosero arrimado a sus carnes, llevaba a menudo distintos tipos de cilicios: "uno era de cadena de hierro con agudas puntas, de que se ceñía muy apretadamente; otro (a mi ver) no menos penoso, de pleita de esparto, que le cogía el medio cuerpo de la cintura arriba; y otro en la misma forma texido de cerdas; otro de cerdas más despiadado, y cruel (que también le cogía el medio cuerpo) y apretávasele de manera a vezes, que le traía con las carnes unido, y al quitársele, se llevava tras sí los pedaços della, dexando el cuerpo lastimadíssimo, lleno de llagas, y vertiendo sangre; y quando assí la sierva de Dios le veía, se gozava, y complacía mucho, como quien se ha vengado de un fiero amigo"60.

Ana de Medina usaba de muchos modos de penitencia. Para mejor sujetar su sensualidad al dominio de la razón, inventaba formas distintas para mortificarse: "traía en los braços unas manillas de hierro, o de áspera soga, en las piernas unas abraçaderas de carda, para el cuerpo lo más suave era el esparto, o cerdas". La beata, además, ceñía su cuerpo con una "faja de lienço de la anchura de un palmo toda colchada de piedrecillas agudas, puestas azia dentro de punta, que pesava tres libras; imitando la prudente culebra, que para desnudarse la camisa vieja, se estrecha entre las piedras ásperas" $"$.

La brutalidad inhumana con que algunas beatas castigavan su cuerpo, no excluía la práctica de otras formas penitenciales que podríamos denominar más normales como el silencio, la huida de las vanidades mundanas, el temor a la fama, el retiro, el cuidado de enfermos y necesitados, etc. Aunque también en estos casos se daban ejemplos extremados como el que referiremos de la beata Elena Martínez.

"Aconteció una vez, que llegó a la puerta un pobre, que tenía muy llagadas las piernas, y como le viesse la santa donzella (que de su natural era en extremo asseada, y limpia, qualquiera cosa asquerosa la causava gran repugnancia, y la rebolvía el estómago) sintió grande horror, más reprehendiéndose de su delicadeza, y poca caridad con el próximo, se concertó con él, que la dexasse lamer las llagas, y que le daría limosna, y assí lo hizo: y saboreóse de suerte en esta grande mortificación, que las veces que podía después ir al hospital, (que era quando la embiavan a los mandados, porque no tenía otro tiempo) iva con gran gozo, llevando cualquier regalillo, que a ella le davan, y algunos trapos limpios, que con mucha diligencia buscava entre sus amigas, y entrávase a la quadra del hospital, que dizen la goleta, donde no ponen, sino a las mugeres llagadas de bubas, y de otras asquerosas enfermedades, lugar donde raras personas se animan a entrar, por el asco, y mal olor, que ay, y haziendo a aquellas miserables las camas, y limpiando sus inmundicias, passava a tanto su caridad, que con la lengua les lamía las llagas podridas, y exprimiéndolas, chu-

59 Ibid., p. 432 y ss.

60 Ibid., p. 431.

61 Ibid., I, p. 383. 
pava la asquerosa materia, y algunas vezes se tragava los trapillos, y hilos empapados della, lo qual hazía con tanta cautela, que apenas los pobres lo echavan de ver, porque viéndolo, lo rehussavan, y quando la veían venir, ocultavan las llagas, pero compelidas de la necessidad, pedíanla, que las diesse algunos trapos limpios, a que ella dezía, que no los avía de dar sino a aquellas, que tuviessen llagas, y que si las tenían, se las mostrassen, y assí necessitadas lo hazían, y ella conseguía su intento: particularmente usava desta mortificación, quando sentía, que aquellas cosas la causavan tan notable asco, que la obligavan a dar arcadas para vomitar, que eran muchas vezes. Mas llegó a vencer de tal suerte aquella natural resistencia, que el beverse después la podre, y lamer las llagas, le era como gustar de un sabroso almívar. Quál sería la dulçura, que abundava en su alma, pues redundava assí en la parte exterior, y gustava su paladar, y lengua las destilaciones del panal dulcíssimo, que avía la misericordia, y piedad fabricado allá en sus entrañas"62.

La excepcional mortificación de Elena Martínez no debe servir para confirmar algunos juicios que se han vertido contra las beatas. El ejemplo de Elena Martínez no es único en la espiritualidad española. Del mismo Patriarca Juan de Ribera se nos dice que curaba las llagas y se las lamía y besaba a su amigo S. Luis Bertrán ${ }^{63}$. También, Pedro de Ribadeneyra en la "Vida de Ignacio de Loyola" que escribió, al referirse a la santidad de vida de Francisco Javier dice: "Señálabase entre todos... en la caridad y misericordia con los pobres y en la entera y perfecta victoria de sí mismo, porque no contento de hacer todos los oficios asquerosos que se podían imaginar, por vencer perfectamente el horror y asco que tenía, lamía y chupaba algunas veces las llagas llenas de materia a los pobres" ${ }^{\text {" }}$.

\section{RELIGIOSIDAD PRECOZ DE LAS BEATAS.}

Difícil parece aceptar que niñas de cuatro o cinco años sintieran la llamada de su espíritu y comenzaran a iniciarse por el camino de la espiritualidad. Sin embargo, los hagiógrafos de las beatas refieren casos así y, si bien, los cuatro o cinco años son una edad muy precoz, los doce o trece años son citados con frecuencia como el momento decisivo en que algunas mujeres toman la decisión de dedicar su vida a la religión como beatas.

El rigor histórico parece estar ausente de la mayoría de las biografías que utilizamos. Escritas con fines hagiográficos y didácticos, resulta difícil precisar dónde termina la veracidad de la anécdota narrada y dónde comienza el relato de hechos inverosímiles o, cuando menos, poco creíbles. Así, cuando el biógrafo de Elena Martínez nos narra, que "siendo niña aún no de cinco años, le dió el Señor luz, y deseo para conocerle, y amarle; y de aqueIla edad començó su Magestad divina a regalarla, y favorecerla con muy especiales misericordias", no sabemos si creerlo, o considerar, por contra, que nos encontramos ante un recurso formal para exagerar la excelencia y la calidad de esta mujer. Lo mismo acontece, cuando leemos que Ana de Medina se retiraba solo a orar a los cuatro años de edad, y, "de cinco años tenía grandes arrobos, que le solían durar todo un día"65.

62 Ibid., II, p. 495.

63 R. ROBRES: San Juan de Ribera, Barcelona, 1960, p. 457.

64 P. RIBADENEYRA: Vida de Ignacio de Loyola, Madrid, 1967, p. 84.

65.PANES, Chrónica..., II, p. 491 y I, p. 381. 
Si excesiva parece la edad de cuatro o cinco años para iniciarse en la vida espiritual, más verosímil resulta el que muchas beatas comenzaran a dejar traslucir su intención de alejarse del mundo y de dedicarse a la religión a partir de los diez años de edad. Es evidente que su decisión no sería todavía firme; pero, mostraban ya síntomas, como la frecuencia en ir a la iglesia, en recibir el sacramento de la comunión y el trato continuo y familiar con personas espirituales, que permitían deducir que, a la hora de elegir forma de vida, estas niñas- mujeres se decantarían por retirarse del mundo y dedicarse por entero a la religión. Este es el caso, por ejemplo, de Elena Martínez, quien, "desde edad de diez años començó a comulgar, sin que se supiese en su casa. Iva por la mañana a aprender de costura, y antes de esto a San Juan del Mercado, donde le aguardava el licenciado Aznar, muy siervo de Dios, y reconciliándola brevemente, la dava luego la comunión..."

También el trato frecuente con personas espirituales influyó en la vida de muchas futuras beatas, decidiéndolas a cambiar de vida. Así, Inés Juana García, maravillada por un sermón que había oído predicar a Fray Cristóbal Moreno, determina apartarse del mundo cuando cuenta sólo doce o trece años de edad. Su decisión fue tan firme que, de vuelta a su casa tras el sermón, se corta el cabello de raíz y obliga a Fray Pedro Nicolás Factor a que pida licencia a sus superiores para que le permitan vestir el hábito de beata de la Tercera orden ${ }^{67}$.

No siempre se podía vestir el hábito de beata a edad tan temprana, pero, cuando esto no era posible quedaba al menos el recurso a la promesa o voto personal. Ya hemos aludido a la extremada precocidad de Ana de Medina; desde muy niña, esta beata dió signos inequívocos de querer dedicarse a la religión. No satisfecha con abrazarse a Cristo interiormente, quería también conformar su exterior a él. "Y en este santo deseo, siendo de diez años, hizo votos de traer el hábito de Nuestro Padre san Francisco, de quien era en extremo devota, pareciéndole que desta suerte se vestiría de unas fuertes armas, con que resistir las saetas venenosas del mundo, del demonio, y la carne"

Es posible que la mayor fama de santidad de unas beatas respecto a otras obligara al biógrafo a exagerar las notas de precocidad y los "favores" alcanzados en la vida espiritual. La fama de Francisca Llopis es incuestionable en el panorama espiritual valenciano. No entramos a valorar ahora la ortodoxia o heterodoxia de su espiritualidad, sólo nos detendremos en su precocidad espiritual. Según su biógrafo, "a los doze años ya tenía oración muy quieta, y frequentava los Sacramentos muy a menudo gozando de mucha devoción, y paz interior, y algunos favores muy especiales de Nuestro Señor: como fue, que estando una vez muy afligida, y triste, por averla dicho su Madre, que ya la avía concertado una casa donde sirviesse, y parecerle, que en ella no tendría lugar para ir a la Iglesia, y darse a la oración, oyó la voz del Señor, que la dixo: Calla, hija; y si supiesses los bienes, que te están guardados? Esta fue la primera habla, que tuvo interior"69.

66 Ibid., II, pp. 492-493.

67 Ibid., pp. 451-452.

68 Ibid., I, p. 385.

69 Ibid., II, p. 695. 
No todas las mujeres fueron tan precoces como los ejemplos hasta aquí detallados. Las circunstancias personales, el simple deseo, el desconocimiento de la manera de vivir de las beatas hizo que muchas mujeres adoptaran esta forma de vida ya en plena madurez. La muerte fortuita de una pedrada de la hija de Isabel Juan hizo que ésta, ya viuda, repartiera su hacienda entre los necesitados y se retirara a vivir como beata de la Tercera orden en una casa que había comparado en Gandía junto al convento de los franciscanos ${ }^{70}$.

\section{LAS BEATAS Y EL MUNDO ECLESIASTICO.}

Las beatas representan una manera de entender la religión que, pese a estar estrechamente vinculada a ciertas órdenes religiosas, podemos considerarla como algo marginal a todo el aparato eclesiástico de la Iglesia. En este sentido, es comprensible que la espiritualidad de estas mujeres estuviera fiscalizada por la Inquisición y por otros organismos de la Iglesia.

No todas las beatas tuvieron problemas con la Inquisición. Su escasa importancia social, lo íntimo de sus experiencias o, simplemente, su manifiesta ortodoxia las mantuvo al margen del Santo Oficio. Otras, en cambio, las que de una manera u otra sobresalieron por la forma peculiar de vivir la espiritualidad, o las que se dieron a toda una serie de excesos, acabaron, más pronto o más tarde, en manos de este tribunal.

El recuerdo de los alumbrados de Toledo pesaba como una losa sobre la conciencia colectiva de la espiritualidad hispana ${ }^{71}$. Cuando todavía no se habían apagado los rescoldos de aquel triste caso, el rebrotamiento del alumbradismo en Extremadura y Andalucía puso a la Inquisición en guardia ante la posibilidad de que aquellos hechos se reprodujeran ${ }^{72}$.

En los casos de alumbradismo de Toledo, Extremadura y Andalucía estaban implicadas mujeres, conocidas genéricamente con el nombre de beatas. Pero, a pesar de que no fueron éstas las responsables últimas de las doctrinas condenadas -tal como refiere J. Caro Baroja ${ }^{73}$, siempre había una personalidad masculina algo desequilibrada sobre la que echar las culpas-, la realidad es que algunas mujeres jugaron un papel destacado en dichas prácticas heterodoxas.

Parco en noticias se muestra el franciscano descalzo Antonio Panes sobre los roces o supuestos procesos inquisitoriales existentes contra las beatas por él biografiadas. Así, de Isabel de la Paz, nos cuenta que el demonio la llevó con otras dos compañeras ante la Inquisición. Allí se las examinó, y no encontrándose nada en ellas contrario a la buena doctrina se las volvió a enviar a sus casas ${ }^{74}$.

El caso de Isabel de la Paz es interesante porque esta mujer tenía ciertas inquietudes intelectuales y gozaba de un gran prestigio espiritual en la ciudad de Cartagena. Isabel escribía discursos morales que eran aprovechados en el púlpito por personajes destacados como

70 Ibid., p. 465.

71 Vid: MARQUEZ, Los alumbrados...

72 Vid: HUERGA, Historia de los Alumbrados...

73 CARO BAROJA, Las formas complejas..., p. 68.

74 PANES, Chrónica..., II, p. 343. 
el Doctor Cámara, que después sería obispo de Salamanca. Para la beata, debía predicarse una doctrina que no tuviera "sutilezas de ingenio, y conceptos curiosos que ningún fruto hazen en las conciencias". Las predicación debía estar dirigida "a la reformación de vida, huyendo los vicios, y procediendo de virtud en virtud, por la imitación de nuestro redemptor Iesu Christo, viviendo pía, sobria, y cástamente en humildad, mortificación, y obediencia, y ajustamiento con el gusto de Dios, para conseguir el dichoso fin de verle, y gozarle por los siglos de la eternidad"75. Pero, la beata no se quedaba aquí en sus orientaciones, sino que consideraba necesaria una reforma a fondo del mundo eclesiástico: "de quien más se quexava el Señor, era de sus ministros, y estado Eclesiástico, que deviendo por su buena elección ser más santos, y reconocidos a su Magestad, y edificar al pueblo con su buen ejemplo, vivían con más libertad, desahogo, y descuido, de que la Justicia divina se hallava indignada, y llovían tan severos castigos, trabajos, y calamidades"76.

También Francisca Llopis tuvo que hacer frente a graves acusaciones procedentes, en su caso, de los frailes dominicos de Valencia. Estos, que no sabían como desacreditar la figura del clérigo Francisco Jerónimo Simón, trataron de hacerlo propagando que el clérigo y la beata vivían y, a veces, dormían juntos en la misma habitación. No parecía importar mucho que en la realidad las cosas no hubieran sido así, la simple propalación del rumor era suficiente para hundir la credibilidad personal y espiritual de cualquiera, mucho más, si la protagonista era una mujer ${ }^{77}$.

El recelo del mundo eclesiástico hacia las beatas resulta comprensible por la proliferación de casos de mujeres que se pretendían espirituales, y que utilizaban su fama en provecho personal, o para divulgar ideas bastante estrafalarias. Ahora bien, con ser comprensible este recelo, no podemos aceptar que esto fuera exclusivo de las mujeres, porque igual o superior número de de casos de estos encontraríamos donde fueron los hombres los protagonistas.

Las mujeres beatas tenían no sólo que parecer espirituales sino, además, estar contínuamente demostrando que lo eran. Beatriz Ana Ruiz, beata de Guardamar con una vida personal bastante atormentada, tuvo que soportar que un predicador de la Cuaresma que la visitó en su casa para probar su virtud, comenzara a acariciarla "y dezirle estava buena, y llena de virtud, y muy adelantada en el servicio de Dios"78.

Mayores problemas de recelos eclesiásticos se producían cuando las mujeres beatas escribían sobre cosas espirituales. Tomás Pérez, biógrafo de Beatriz Ana Ruiz, acierta plenamente cuando al referirse a los escritos o revelaciones de mujeres, dice: "Otra duda anda en estas causas como imprescindible, y conexa con la entidad de la persona; fundada en la condición, y sexo del sugeto que recibe la Revelación; y tan perentoria de examinarse, que sólo por el artículo de ser algunos libros dictados, y escritos por muger, aunque de asuntos útiles, y graves, les impugnaron varones juiciosos, y peritos. Assí lo refiere Martín del Río.

75 Ibid., p. 367.

76 Ibid., pp. 367-368.

77 Sobre la figura del clérigo Francisco Jerónimo Simón y toda la polémica que se suscita en Valencia a su muerte, ver el capítulo de mi tésis "Francisco Jerónimo Simón", pp. 213-385.

78 PEREZ, Vida de la Venerable..., p. 36. 
La inevitable sospecha de estas personas, estriva: parte en la índole mugeril, dispuesta, y pronta a engañarse, y engañar; y parte estriva en la prohibición iterada de san Pablo, negando a toda muger no sólo el plácito, si también el permisso de enseñar. Esta prohibición recae más de lleno, y costriñe más en esta ocasión, que en otra cualquiera: pues todas las Revelaciones de la venerable Madre Sor beatriz Ana Ruiz son Doctrinas, y todo su contenido es continuada enseñanza: y ésta es la materia expréssamente prohibida por san Pablo a los de tal sexo"79.

Como casi siempre ocurría, también ahora, Tomás Pérez se veía en la obligación de recurrir a los casos fuera de toda sospecha de Santa Brígida, Santa Hildegarda, Santa Catalina, etc., y áun, advirtiendo: "pero siempre que expongan su doctrina sin ostentación"80.

Finalmente, como muestra del recelo con que el mundo eclesiástico veía los ejemplos espirituales protagonizados por mujeres, recurriremos de nuevo a la biografía de Isabel de la Paz.

Enterado el Provincial de los franciscanos descalzos de Valencia que Isabel se había atrevido a escribir cartas espirituales a algunos religiosos, mandó llamarla y, delante de los religiosos más graves del convento, le espetó: "que era una altiva, y presumptuosa, que fingía oráculos, y revelaciones, para engañar el mundo, y que en la Provincia no avía Beata semejante a ella, que quería hazerse Maestra de sus Maestros, y padres espirituales; por fin de todo amenaçóla con la Inquisición...". Acabada la reprimenda del Provincial, que la beata había soportado bastante estoicamente, le respondió: "Padre Provincial, yo me enmendaré, huélgome que me aya advertido de mi ignorancia: hija soy de obediencia, no soy mía, no saldré un punto de lo que me mandare". Poco satisfecho todavía el fraile con la respuesta, la obligó a firmar una serie de cartas, escritas por él mismo y dirigidas a aquellos a quienes Isabel lo había hecho. A pesar de todo, el Provincial no acababa de darse por satisfecho, y quiso examinar el espíritu de la beata, "y como varón tan científico, y de tanta viveza, y fondo, tentó el de la sierva de Dios, y hallólo en todo tan bien fundado, que el rigor, de que avía usado hasta entonces, le convirtió en benignidad, y afecto, alabando, y estimando mucho su singular virtud"81.

\section{INFLUJO SOCIAL Y MAGISTERIO ESPIRITUAL DE LAS BEATAS.}

En líneas generales, las beatas fueron mujeres solitarias que vivieron su espiritualidad de forma muy íntima o, como mucho, en comunidad con otras mujeres. Asimismo, las beatas tuvieron trato espiritual únicamente con sus maestros y confesores; se relacionaron de modo familiar con sus vecinos y no lograron dejar una fuerte impronta entre ellos. En muchos casos, los mismos convecinos de las beatas las repudiaron considerándolas gentes extrañas y de poco juicio. Sin embargo, hubo beatas que fueron estimadas y que, incluso, alcanzaron una notable fama en vida. Este es el caso, por ejemplo, de Isabel de la Paz. "Tan

79 Ibid., p. 270.

80 Ibid., p. 271.

81 PANES, Chrónica..., II, pp. 346-347. 
grande era el fuego del divino amor, que contínuamente ardía en el pecho desta sierva de Dios (dize su bienhechor) que robava los coraçones de quantos la hablavan, tratavan, y comunicavan: cosa muy notoria en toda la Ciudad, y no era menester más de oirla una sola palabra, para quedarse enagenados de sí por muy largo tiempo, especialmente religiosos, y gente de espíritu" siempre se está en un rincón y viendo ella, que tantos la ivan allí a buscar se afligía muchíssimo, y dezía a Dios: Señor no haríades, que no fuesse nadie a mi casa? no ay otros que les traten mejor que vos? y dando estas quexas a nuestro Señor muchas vezes, dos dellas oyó en lo interior de su alma, que le dixo el Señor: Hija traigotelos a ti, para que se salven, porque he determinado salvar a los que contigo trataren"83.

Francisca Llopis era muy conocida en Valencia en 1612. Este año, la muerte del clérigo Francisco Jerónimo Simón, con el que le unía una estrecha relación personal y espiritual, la catapultó a la fama. A partir de ese momento, ya no encuentra sosiego. "Como con la manifestación del Venerable Mosén Gerónimo Simón, no ha podido traslucirse algo de lo que es Francisca su madre fidelíssima (como él la nombró en su testamento en que la instituyó heredera) toda Valencia la busca, todos la desean conocer, y hablar". Francisca trata de rehuir esta fama, no sabe ya adonde ir, "todo es buscar traças como esconderse, y huir de los señores, y señoras, que la buscan, yéndose fuera de Valencia, ya a un lugarcillo, ya a otro, ya ocultándose por diversas iglesias, porque no atinen adonde va". La beata no busca la fama y el favor del pueblo, pues si fuera esto lo que deseara, como dice Antonio Panes, "bien a manos llenas pudiera ganarlas en esta ocasión". Pero, para ella importan poco las glorias del mundo. Intenta vivir su espiritualidad de forma personal e íntima, y, por eso, cuando toda Valencia estalla en fiestas en honor de su ahijado espiritual, Francisco Jerónimo Simón, "ella no se alegra en otra cosa más que en verse sola, y que todos la dexen y olviden" $\$ 4$.

La soledad buscada y anhelada por Isabel de la Paz y Francisca Llopis no siempre fue compartida por otras beatas. Hubo algunas que buscaron y fomentaron el aplauso y el favor del pueblo, incluso, sobrepasando los límites de sus humanas posiblidades, también de las espirituales, y que hicieron el más estrepitoso ridículo cuando quisieron convertirse en pitonisas, sanadoras milagrosas y otros quehaceres bien poco espirituales.

En algunas ocasiones, las beatas, o sus cuerpos, fueron utilizados servilmente por las órdenes religiosas. Así, no resulta extraño encontrar disputas entre órdenes religiosas por conseguir enterrar en sus iglesias los cuerpos de algunas de estas mujeres, que gozaron en vida de cierta fama de santidad. Con ello se pretendía atraer hacia las iglesias, no tanto a los fieles, como, lo que resulta más mezquino, las limosnas de éstos con el señuelo de tener enterrado en la iglesia del convento un cuerpo u otro de beata. Pero, la mayoría de la veces, el pueblo distinguía bien unas beatas de otras. Por eso, no resulta extraño que las autoridades eclesiásticas, ya de por sí recelosas de estas mujeres, trataran de cortar las muestras de fervor que el pueblo las tributaba. Esto fue lo que ocurrió a la muerte de Elena

82 Ibid., p. 364.

83 Ibid., p. 365.

84 Ibid., p. 709. 
Martínez, cuando el Arzobispo de Valencia ordenó que se la enterrara "más aprisa de lo que quisieron los fieles" $"$. Lo mismo aconteció con Francisca Llopis, que fallecida el 18 de mayo de 1650, la enterraron al día siguiente pues el Arzobispo, según Antonio Panes, ordenó que no se dilatara más su entierro porque tenía miedo que se volvieran a producir las extraordinarias muestras de fervor popular que habían tenido lugar a la muerte del clérigo Francisco Jerónimo Simón en $1612^{86}$.

Alrededor de casi todas las beatas vemos merodear siempre a personas eclesiásticas. En la mayoría de los casos son confesores y maestros espirituales; pero se hace difícil discernir hasta qué punto éstos se limitaban solamente a guiar espiritualmente a estas mujeres. Los hechos inducen a pensar, que al igual como en los monasterios de monjas existían las "devociones", también las beatas tenían sus devotos que las visitaban y les pedían consejos espirituales. Esto quedó suficientemente demostrado en el caso de Isabel de la Paz, en cuyo derredor vimos se movían algunos religiosos con los que la beata mantenía una activa correspondencia espiritual.

Si nos circunscribimos ahora a los nombres más significativos de aquellos que, de una manera u otra, se relacionan con las beatas, vemos que están presentes los de todas las principales figuras de la espiritualidad valenciana del siglo XVII.

Unidos a la vida de Margarita Agulló figuran personajes tan significativos como el Patriarca Juan de Ribera, Rodrigo de Solís, Pedro Nicolás Factor, Luis Bertrán, Cristóbal Moreno, Jaime Sanchis, etc. El Patriarca mantuvo una singular relación con esta beata. Escribió el prólogo de su vida, la llevó a vivir a una de sus casas y la enterró con grandes muestras de devoción en la Iglesia de los Capuchinos, hasta que estviera terminada la Iglesia del Colegio del Corpus Christi, donde está hoy enterrada. Además, Ribera relacionó a la beata con Fray Luis de Granada y, a través de éste, con la monja de Lisboa, sor María de la Visitación ${ }^{87}$.

El magisterio espiritual de Francisca Llopis sobresale del resto de las beatas aquí estudiadas. Para muchos espirituales de Valencia, Francisca era su madre y su maestra espiritual.

El jesuita Gerónimo Mur fue confesor de Francisca durante siete años. La beata era todavía muy joven, pero esto no fue óbice para que dejara una huella profunda en el jesuita, hasta el extremo de hacerle manifestar: "si estuviesse con las personas más principales del mundo, y con la misma Reyna..., las dexava a todas para confessarla a ella, tanta era la pureza, y gracia, que descubría en su bendita ánima, y lo que estimava su trato" ${ }^{\text {"88. }}$.

Al surgir en Valencia la polémica de la santidad de Francisco Jerónimo Simón, Francisca Llopis vivió momentos muy amargos. Algunos eclesiásticos cuestionaron la espiritualidad de la beata y la acusaron de haber mantenido relaciones con el clérigo Simón. En esos momentos, muchas personas que decían estimarla la abandonaron. Otros, en cam-

85 Ibid., p. 528.

86 Ibid., p. 793.

87 Un análisis detallado de las relaciones de Ribera con la beata Agullona puede verse en el capítulo de mi tésis, "San Juan de Ribera y la espiritualidad valenciana del siglo XVI", pp. 160-212.

88 PANES, Chrónica..., II, p. 687. 
bio, mantuvieron su fidelidad hacia ella, como el jesuita Miguel Julián: "Si supiesse Francisca lo que en su favor la Compañía ha escrito, defendiendo los nombres más insignes della su inocencia, y seguridad de espíritu, la causaría grande confusión". La Compañia de Jesús estimaba sobremanera a Francisca, como lo demuestra que llegaran a sacar una licencia para poder enterrarla en su Iglesia ${ }^{89}$.

Otros personajes que trataron a Francisca Llopis fueron los frailes jerónimos Bartuli, Romeu y Montalván, el dominico Domingo Anadón, los mercedarios Nolasco y Gralla, los carmelitas Carranza y Roca, los capuchinos Eugenio de Oliva y Luis de Valencia, los clérigos Juan García, Barberán, Felipe Pesantes, Nauri y Jacinto Maya y, finalmente, varias generaciones de franciscanos descalzos del convento de San Juan de la Ribera de Valencia ${ }^{90}$. La huella que deja Francisca Llopis en la espiritualidad valenciana es tan profunda que se prolonga hasta finales del siglo XVII. Varias generaciones de espirituales valencianos vieron en ella una madre y una maestra. Si la beata bebe en el franciscano descalzo Antonio Sobrino su espiritualidad, después, cuando falte Sobrino, ella será capaz de transmitir sus más íntimas vivencias a otros espirituales como al tambien franciscano descalzo Antonio Panes y, sobre todo, al aragonés Miguel Molinos ${ }^{91}$.

\section{LA ESPIRITUALIDAD DE LAS BEATAS.}

No quisiéramos terminar este breve estudio de las mujeres beatas sin hacer referencia a su método y manera de entender la espiritualidad.

Tal como dijimos en páginas atrás, las beatas son, en general, gente del pueblo, con un nivel cultural nulo. Por tanto, se hace difícil creer que pudieran acceder a la lectura de los libros de espiritualidad que proliferaban en la época. Y si no sabían leer, es evidente que la práctica metódica de muchos años y las enseñanzas que les facilitaban sus confesores y maestros espirituales fue lo que les permitió adquirir un método de espiritualidad capaz de satisfacer sus inquietudes.

Desde los tiempos remotos de aquel gran primer maestro místico que fue Dionisio Aeropagita, hasta las primeras décadas del siglo XVII, la espiritualidad se había visto enriquecida con las aportaciones teóricas de grandes autores. Autores y escuelas espirituales rivalizaban entre sí por exponer el método más adecuado y más seguro para acceder a la espiritualidad. Ascética y mística, oración vocal y oración mental, etc., eran algunas de las fórmulas que podían aceptar quienes se adentraban por este camino. Sin embargo, las beatas no sabían de estas teorías y rivalidades entre escuelas, y lo que hacían era conjugar diferentes modos de oración en su vida espiritual. De este modo, oración vocal, meditaciones sensibles, sacrificios y mortificaciones, movimientos anagógicos, visiones, revelaciones, desposorios espirituales, arrobos, éxtasis, etc., estaban presentes, en mayor o menor medi$\mathrm{da}$, en su vida espiritual. En algunos casos, observamos que algunas se decantaban por un

89 Ibid., p. 687

90 Ibid., p. 687-689

91 Información sobre estos personajes espirituales que se mueven en el entorno de Francisca Llopis pueden verse en el capítulo de mi tésis "La espiritualidad valenciana y Miguel Molinos", pp. 686-728 
sistema específico de oración, pero son las excepciones, pues la mayoría no eran capaces de discernir entre un sistema u otro.

Los confesores y maestros espirituales tienen un papel destacado en la elección espiritual que hacen las beatas. En muchas ocasiones es por medio de ellos como conocemos los sistemas de oracion de las beatas. Los confesores y maestros espirituales escribieron o les ordenaron a las beatas que lo hicieran la manera como vivían su espiritualidad y las experiencias que tenían. Así es como Antonio Sobrino fue capaz de escribir tres gruesos volúmenes sobre los favores divinos que le fueron concedidos a Francisca Llopis, o como Tomás Pérez pudo comentar las visiones simbólicas que Beatriz Ana Ruiz le había dictado a su confesor Miguel Pujalte. De este modo es como conocemos también la espiritualidad de Margarita Agulló, ya que fue el Patriarca Don Juan de Ribera quien le ordenó que escribiera sobre ella ${ }^{92}$.

Si tuviéramos que esbozar un sistema de oración común a todas las beatas, veríamos como la mayoría de ellas comenzaban su andadura espiritual con la práctica de la oración vocal, se adentraban después en la meditación sensible de los misterios de la humanidad de Cristo, hasta ascender, por medio de la oracón mental, a las cotas más altas de la contemplación mística. Una vez aquí, disfrutaban de revelaciones, visiones, éxtasis, etc. Pero, esto sería sólo un esquema general, que casi nunca se cumpliría, porque cada beata era un mundo distinto a las demás.

Ana García Rubia, al iniciar su vida espiritual, "su oración frecuente era la vocal, rezando casi contínuamente, y trayendo siempre el rosario en la mano"93. Más adelante, "fue el Señor servido de darle un Padre espiritual, que la metiesse por camino interior...", y éste la instruyó en el modo y orden que debía seguir en sus ejercicios espirituales cotidianos. La beata debió gozar de elevados deleites místicos, pero como precisa su biógrafo, "como sólo los comunicava con sus padres espirituales, los quales faltaron no pueden saberse, mas no ay duda fueron muy grandes, siendo tan liberal y abundante de dones el Señor a quien contínuamente buscava, posseía, y amava, y siendo (como dize san Agustín) la oración una subida, que el alma haze de lo terreno, a lo celestial, una inquisición de las cosas supremas, y desseo ardiente de las invisibles, esto gozava contínuamente quien tenía continua oración"94.

Isabel de la Paz, la beata con nivel cultural más alto de las estudiadas aquí, escribió ella misma las experiencias espirituales que vivía. "La compostura interior con que mi alma está de continuo, y sin apartarse ni un punto de la presencia de este Señor, es tener un gran

92 Uno de Ios volúmenes escritos por Fray Antonio Sobrino sobre las revelaciones de Francisca Llopis hemos podido verlo en la Biblioteca que los franciscanos de Valencia tienen en el convento de Santo Espíritu del Monte (Gilet). Las revelaciones espirituales de Beatriz Ana Ruiz pueden leerse en: PEREZ, Vida de la Venerable...Finalmente, los escritos espirituales de Margarita Agullón a que hacemos alusión están en: ALCOVER, Historia de la Congregación...

93 PANES, Chrónica..., II, p. 429.

94 Ibid., p. 483 y 441 . "El Padre espiritual de la beata Ana García Rubia fue D. Juan Alarcón, señor de la villa de Bonache, quien tocado de impulso divino e ilustrado de la soberana luz, dexó el estado, y ordenándose Sacerdote, se retiró a una ermita a dos leguas de Honrubia en el marquesado de Villena, Obispado de Cuenca, donde se dedicó al ocio santo de ta oración". 
conocimiento, del qual procede una gran reverencia, y de aquí un grande amor, que siempre ama con silencio, y tranquilidad de los sentidos, y potencias, aguardando, que este Señor mande, y esto todo con gran claridad en este Señor, sin que a esta claridad, silencio, y tranquilidad le impida cosa alguna exterior, ni el ruido, ni el comer, ni el bever, ni el hablar. Esto me enseñó el Señor (que siempre ha sido, y es maestro de mi alma) mostrándome a su Madre Santíssima, y diziéndome: Mira, hija, a mi madre, como nunca se aparta de mí, vi con gran claridad aquel puríssimo coraçón de la Virgen como siempre mirava a su amado hijo. Dióme también este Señor a los Angeles, para que dellos tomasse lición, y mi alma los imitasse, como los imitan en aquella suspensión, con que de ordinario assisten delante de Nuestro Señor, de donde me sucede, que oyendo muchas vezes hablar cosas diferentes de lo que mi alma conversa, no atiendo, a lo que dicen, y preguntándome si les he entendido, respondo según aquel modo, y lenguaje con que mi alma está en la presencia deste Señor, y assí digo: Gracias a Dios. Bendito sea Dios. O Dios de Magestad inmensa ¡O Señor! Engrandecido seas, alábente, y dénte gloria todas las criaturas. Con esta suspensión, que mi alma tiene delante deste Señor, sin que sea necessario otra cosa más, que amor, amando da gracias, amando ofrece, amando pide; y amando recibe"

Más metódico es el sistema que sigue Ana de Medina en su espiritualidad. En la vida de esta beata todo es precoz y desmesurado. A pesar de gozar de deleites místicos desde edad muy temprana, no por eso descuidaba el tiempo que dedicaba a la oración. Las diez horas que cada día tenía de oración le servían de preparación para ascender por las diferentes moradas del castillo interior. "De la frecuencia de la oración, vino a elevarse tanto su espíritu, que eran muy continuos en ella, quanto extraordinarios, y vehementes los arrobos, y éxtasis, assí estando sana, como enferma: que como el accidente más grave, de que adolecía, era de amor, ningún otro impedía su excessiva, y amorosa passión. Demás de aquel tiempo, que de propósito orava, todo lo restante era otra disimulada oración, porque en cualquier ocupación y exercicio, no sólo iva en la presencia de Dios; pero sabiendo, que el centro, y fondo del alma es trono, y paraíso suyo, donde tiene sus más regaladas delicias, allí con ansiosas aspiraciones le buscava, y abraçándole con íntimo gozo, assí se suspendía en sus pacíficos, y quietos braços, que andava casi siempre absorta"96.

Francisca Llopis no despreciaba la oración vocal, le gustaba la meditación sensible y sentía una devoción particular por el Santíssimo Sacramento y por la Virgen; pero, tenía mayor predilección por la oración mental, porque en ella gozaba de los mayores deleites místicos. Estos eran tan elevados, que su biógrafo no encontraba palabras para narrarlos: "Querer dar alcance mi pluma a esta garza, o Aguila caudal, para dezir el eminente grado de elevación mental, donde llegó su arrebatado espíritu, fuera presunción vana: pues ella misma, aunque lo experimentava, no hallava modo con que declararlo: porque bien puede el alma con el ímpetu del inflamado amor calarse a los profundos senos del piélago inmenso de Dios: bien puede gustar la infinita suavidad, y dulçura en su manantial, y fuente: bien puede contemplar la inaccessible luz, más no dezir lo que oyó, ni vió" ${ }^{97}$.

95 Ibid., p. 353.

96 Ibid., I, p. 382.

97 Ibid., II, pp. 735-736. 
El ejercicio espiritual de Francisca Llopis era diferente "del que nuestro modo humano acostumbra". Habiendo sentido desde muy joven el llamamiento de Dios, su espíritu permanecía de contínuo elevado; y aunque sufría momentos de confusión en su vida cotidiana, "en la otra región suprema que confina con lo celestial, y divino, siempre reverberava, como en limpio cristal la soberana lumbre; y era encendida de su ardiente rayo; tirando con tan dulce fuerça las potencias del alma, que no podían casi ordinariamente dexar de inclinarse a aquel centro, con una propensión vehemente, y un suavíssimo, y deleitosíssimo peso"

Francisca Llopis era instruida en la oración por medio de revelaciones intelectuales. Así fue como descubrió la oración mental y los frutos que en la misma podía esperar. La espiritualidad de Francisca Llopis se encuadra de lleno en la mística. No hay rechazo de métodos ascéticos como sacrificios, mortificaciones, devociones, etc. Todo ello lo acepta la beata, pero, sólo como preparación para la contemplación mística. En este sentido, pues, es como resulta comprensible que para Francisca aproveche más un quarto de hora de oración mental "con recogimiento de los sentidos, y potencias, y con resignación, y humildad", que cinco días de "exercicios penales, de cilicios, disciplinas, ayunos, y dormir en tablas", porque con esto se aflige el cuerpo, y con lo otro "se purifica, y perfecciona el alma". De igual modo, más agradable resulta a Dios una hora de quieta y devota oración, que el ir a romerías y peregrinaciones, porque "en la oración aprovecha a sí, y a aquellos por quien ora; es de grande regalo a Dios, y merece gran peso de gloria; en la peregrinación de ordinario se distrae el ánima, y derrama el sentido, enflaqueciéndose la virtud"'99.

Los espirituales han intentado explicar el ascenso del alma en la oración con diferentes metáforas. Como moradas de un castillo interior lo explicaba Teresa de Jesús y como cielos lo hace Francisca Llopis en una gradación de uno a once, que no son sino repetición de las clásicas tres vías: purgativa, iluminativa y unitiva. "El primero es el conocimiento profundo de su propia vileza, y nada: El segundo cielo es la perfecta renunciación, y menosprecio de todo lo que es transitorio, y despegamiento de las criaturas: El tercero cielo es la justicia espiritual, virtud, que a cada uno, y a cada cosa da lo que es suyo, y ajustando el alma con el querer divino, ciñe, y estrecha la libertad, y voluntad propia para que nada se descompasse, ni desordene... El quarto cielo es la limpieza del coraçón, y el cuerpo: El quinto cielo es la mansedumbre, que excluye del ánima toda perturbación, amargura, y desabrimiento consigo, y los próximos: El sexto cielo es la paz... El séptimo cielo es el de la caridad, y misericordia con que el justo abraça, y remedia todas las necessidades del próximo, por sí en lo que puede, y en lo que no puede, acudiendo a Dios: El octavo cielo es el del puríssimo amor con que se ajunta a Dios: El nono cielo es el silencio interior, y entrega del alma olvidada de sí: El dézimo cielo es el de la divina contemplación, introduzida el ánima a lo interior, adonde oye las divinas hablas, o siente las secretas, y muy delicadas inspiraciones, e ilustraciones, sin hazer más de las recibir. Y el último, y como impíreo cielo, es lo más supremo, e íntimo del espíritu, adonde tiene su assiento, y trono el Señor, y adonde las cosas celestiales, (aunque con el velo de la $\mathrm{Fe}$ ) se pueden gozar, y sentir"100.

98 Ibid., p. 736.

99 Ibid., p. 736 .

100 Ibid., pp. 737-738. 
En definitiva, muchas y variadas eran las maneras con que estas mujeres vivían su espiritualidad y entendían debía ser la vida de beata, como para que superemos esa cierta facilidad que todavía subsiste por los juicios descalificadores hacia ellas. Es evidente que existieron casos de mujeres que motivaron estos juicios, pero no podemos sino reconocer que éstos fueron los menos, y que resultan injustas las generalizaciones peyorativas que se han hecho hacia este mundo singular y enigmático de las mujeres beatas.

Para muchos espirituales y doctos varones de la época, aquellos que no tenían "conocimientos" no debían adentrarse por los caminos difíciles de la contemplación mística. Los errores cometidos por algunos de los llamados alumbrados de Toledo y por los de Extremadura hizo que se mirase con aversión que gentes laicas y, sobre todo, mujeres se dieran a la contemplación y en ella disfrutaran de arrobos, éxtasis, revelaciones, etc. Parecía no importar demasiado que dichas personas accedieran a dichos deleites guiadas casi siempre por confesores o guías espirituales experimentados; en el fondo, persistía siempre el temor a que todo derivara en formas espirituales contrarias a la ortodoxia. Para estos temerosos, los laicos debían conformarse con las formas más asequibles de la oración vocal, de las meditaciones, de los sacrificios y penitencias y de toda la parafernalia litúrgica existente. La oración mental y la contemplación mística estaban reservadas para los eclesiásticos, sobre todo, para los religiosos que, en conventos y monasterios, se dedicaban a Dios exclusivamente. Sin embargo, a pesar de las prohibiciones y de los temores de algunos, las mujeres beatas demostraron que con su forma de vivir podían ser un ejemplo para el resto y, lo que parece más importante, podían desarrollar su propia individualidad de mujer al margen de rígidas ataduras eclesiásticas. 